\title{
A DEMOCRACIA DELIBERATIVA APLICADA NO ÂMBITO DO PODER EXECUTIVO: MECANISMOS DE PARTICIPAÇÃO DIALÓGICA E A QUESTÃO DA VINCULAÇÃO DO ADMINISTRADOR À ESFERA PÚBLICA
}

\section{DELIBERATIVE DEMOCRACY APPLIED IN THE CONTEXT OF THE EXECUTIVE POWER: MECHANISMS OF DIALOGIC PARTICIPATION AND THE ISSUE OF THE ADMINISTRATOR LINKING TO PUBLIC SPHERE}

\author{
${ }^{1}$ Sheila Sampaio Gonçalves Barreto
}

\section{RESUMO}

O presente trabalho tem por objetivo analisar a aplicação da Democracia Deliberativa, delineada por Jürgen Habermas, na esfera da Administração Pública, como forma de ampliar o conceito de democracia, incluindo o homem como elemento essencial no debate político. Para isso, faz-se importante a instituição de espaços adequados para as deliberações e formulações do consenso construído na esfera pública, como também do procedimentalismo normativo capaz de nortear as premissas basilares do debate, a fim de que o trato dialógico siga regras e alcance o entendimento. Nesse aspecto, considerações propedêuticas serão abordadas acerca da Teoria do Discurso, tais como o agir comunicativo, a esfera pública e a autolegislação, uma vez que a compreensão dessas expressões permite formular um mecanismo procedimentalizado de atuação do cidadão no Poder Administrativo. Com essa perspectiva, o estudo da participação social no Brasil será realizado tomando por base a abordagem deliberativa e procedimentalizada, sem deixar de considerar as críticas pertinentes. Outro ponto a ser examinado é a questão da vinculação do administrador ao que fora pactuado na esfera pública mediante regras procedimentais, vinculação esta que será abordada considerando as similitudes e diferenças entre a Teoria da Eclusa de Habermas e as Assembleias Primárias de Condorcet, com o desiderato de encontrar o limite da participação deliberativa na condução das escolhas públicas.

Palavras-chave: Democracia deliberativa, Administração pública, Participação social, Teoria da eclusa, Assembleias primárias

\footnotetext{
${ }^{1}$ Professora na Faculdade Estácio do Rio Grande do Norte, Rio Grande do Norte (Brasil). Mestrado em Direito pela Universidade Federal do Rio Grande do Norte (UFRN), Rio Grande do Norte (Brasil). E-mail: s.barreto11@yahoo.com.br
} 


\begin{abstract}
This study aims to examine the application of Deliberative Democracy, outlined by Jürgen Habermas, within the sphere of the Public Administration, in order to extend the concept of democracy, including the population as a key element in the political debate. For this, it is important the establishment of adequate spaces for deliberations and formulations of built consensus in the public sphere, as well as the normative Proceduralism able to guide the fundamental premises of the debatein order to that dialogue tract follow rules and reach for the understanding. In this regard, propaedeutic considerations will be addressed on the Discourse Theory, such as communicative action, the public sphere and self-legislation, as the understanding of these expressions allows formulate a procedimentalizado mechanism of action of the citizen in the Administrative Power. At the prospect, the study of social participation in Brazil will be conducted building on deliberative approachwhile still considering the pertinent criticisms. Another aspect to be considered is the question of the administrator link to what was agreed in the public sphere by procedural rules such link that will be addressed considering the similarities and differences between the "Theory Sluice" by Habermas and the Primary Assemblies of Condorcet, with in order to find the limit of deliberative participation in the conduct of public choices.
\end{abstract}

Keywords: Deliberative democracy, Public administration, Social participation, Theory sluice, Primary assemblies

\title{
1 INTRODUÇÃO
}


A democracia sempre revelou muita polêmica quanto ao modo como as Instituições Democráticas concedem espaço para a participação efetiva dos cidadãos em suas estruturas precípuas de poder.

Em verdade, há um ponto de tensão entre democracia e o exercício da soberania popular, esta, de acordo com a conjuntura política atual perfaz-se na representação, eleição e voto do povo para eleger aqueles que representaram interessem gerais, em tese.

O presente artigo tem por objetivo analisar a participação popular nas Administração Pública como mecanismo de tornar a gestão mais democrática e hígida, além de contribuir para o fortalecimento do princípio constitucional da soberania popular.

Nessa perspectiva, a democracia será abordada sob o aspecto deliberativo da Teoria Discursiva de Jürgen Habermas, afim de se estruturar uma aplicação possível de interação entre Administração Pública e sociedade pautada no contínuo diálogo, nos fluxos comunicacionais entre a periferia e o Poder Administrativo.

E, para tercer o entendimento necessário para a compreensão de como Habermas funda o pensamento pertinente aos fluxos dialógicos na Administração Pública, será abordada, propedeuticamente, estruturas importantes como "mundo da vida", "esfera pública" e autolegislação. Em seguida, o Decreto de Participação Popular será analisado como manifestação procedimentalizada de participação popular na esfera do Poder Executivo Federal e, ao final os elementos de coesão e de dissonância entre as Teorias de Habermas e Condorcet sobre o limite da influência que assuntos tratados na esfera pública podem exercer sobre o Poder Central.

O trabalho em tela tem como objetivo geral a compreensão de uma visão mais larga sobre a participação cidadã no contexto democrático da deliberação, contida na Teoria do Discurso de Habermas, aplicada ao Poder Executivo como forma de estreitamento da inteiração entre cidadãos e Instituições Democráticas e efetivação, por meio do procedimento, do sentido de soberania popular.

O objetivo específico concentra-se na análise dos argumentos fundantes da Democracia Deliberativa para propiciar o espaço adequado de conformação democrática à Administração Pública e, dessa forma, vislumbrar o homem como ator ativo e político, por meio do debate público, de uma gestão a qual lhe pertence. 
A metodologia se firma na pesquisa em doutrinas, periódicos e artigos científicos sobre democracia, participação, deliberação e cidadania, tomando como ponto inicial a doutrina de Haberma, utilizando abordagem teórico-descritiva, para fundamentar a lógica discursiva e democrática no plano do exercício da atividade pública de administrar democraticamente com a interação cidadã na abordagem de temáticas públicas relevantes.

\section{CONSIDERAÇÕES PROPEDEUTICAS ACERCA DA TEORIA DO DISCURSO}

O estudo sobre a aplicação da Deliberação Democrática nos Poderes do Estado ainda se revela bastante teórica e de pouca aplicabilidade, posto que não atendem as regras discursivas da deliberação segundo os ensinamentos de Jürgen Habermas.

O objetivo do presente artigo é delinear o aspecto democrático deliberativo na seara do Poder Executivo e, para tanto, faz-se necessário apontar alguns conceitos idealizados por Habermas, notadamente ao que pertence à esfera pública, mundo da vida e aoutolegislação

Nesse sentido, é possível depreender que, a partir do ato da fala, da comunicação, constrói-se uma forma de análise do direito e da democracia sob o aspecto sociológico, considerando o homem em sociedade como ator principal para uma atuação democrática de participação plena, dialógica, e não apenas pautada na participação rígida de escolha dos representantes políticos.

E, é no "mundo da vida" que nasce a observação dinâmica da linguagem e a influência que os "portadores" da vontade social podem exercer no cenário político, manifestando, assim, referências para a análise da democracia deliberativa.

O mundo da vida, na linguagem habermasiana, “[...] estrutura-se através de tradições culturais, de ordens institucionais e de identidades criadas através de processos de socialização", mas não pode ser equiparado a uma organização, a uma associação ou uma coletividade formada por indivíduos, pois o mundo da vida é construído sobre a interação da linguagem considerando a diversidade cultural da sociedade. Engessa-lo tornaria o "mundo da vida" estanque e sem interação e é, juntamente a interação, a socialização dos membros que permite o "jogo conjunto", contínuo e fluxo de atuação de práticas cotidianas (HABERMAS, 1990, p. 100).

O mundo da vida é o palco dos acontecimentos linguísticos, no qual ocorre a interação das pessoas e toda a diversidade de cultural podem ser vivenciadas, em um plexo contínuo estruturado sobre o agir comunicativo (GÓES, 2013, p. 70). 
Habermas, em "Verdade e Justificação" foca o "mundo da vida" para um entendimento mútuo dos atores sociais quem procuram, no ordenamento social, alcançar o consenso sobre os problemas que ocorrem em suas vidas. Mas, modernamente a interação acontece levando em consideração a validade sobre o tema da verdade, da justiça e do gosto, envolvendo elementos como ciência e técnica, direito e moral, arte e crítica. E, cada sistema funcional, criado a partir da instituição nuclear da sociedade (família, religião e ordem jurídica) passa a desenvolver uma vida particular porque possuem agir comunicativo próprio. Assim, pode-se falar que o dinheiro e o poder administrativo têm linguagens que só diz respeito ao seu próprio sistema, mas isso não significa uma contradição quanto a um aparente isolamento da linguagem. A linguagem, no caso, se ramifica dentro do próprio sistema em particular, entretanto tem suas origens fora dele e, para a sociedade deve estar aberto à comunicação para manutenção interativa da linguagem (HABERMAS, 2004, p. 320).

A compreensão, mesmo em breve síntese, de mundo da vida e da dialeticidade social que acontece em seu terreno é peça elementar para o passo seguinte: a esfera pública, pois é nela onde se organizam e se orientam as vontades individuais para a vontade social, ou geral.

A esfera pública sempre teve um conceito vacilante, variável de acordo com a história e com pensamentos revolucionários, mas vinculada ao espeça destinado à "opinião pública”. Habermas, por sua vez, confere ao seu conceito elementos que incorporam o poder político e opinião crítica (HABERMAS, 2003, p. 274), favorecendo a circulação de questões.

A esfera pública representa mais que a própria expressão linguística que o seu nome pode transparecer. Não se trata de algo rígido, preso a um espaço delimitado, hermético e inamovível, muito pelo contrário, a esfera pública proposta por Habermas é viva e palco das manifestações da fala.

A esfera pública política é tratada como acontecimento da sociedade civil e também vislumbrada para uma teoria democrática, sendo tida, no âmbito da sociedade civil, como uma "caixa de ressonância" que ecoa os problemas nascentes do seio social e que precisa ser amparada por um sistema político. Nesse sentido, “[...] a esfera pública é um sistema de alarme dotado de sensores não especializados, porém, sensíveis no âmbito de toda a sociedade" (Habermas, 2011, p. 92).

Nesse sentido, a noção de esfera pública ganha conotação relevante frente aos estudos sobre democracia e interesses sociais.

Habermas, em Direito e Democracia II, descreve a esfera pública da seguinte maneira: 
Esfera ou espaço público é um fenômeno social elementar, do mesmo modo que a ação, o ator, o grupo ou a coletividade; porém, ele não é arrolado entre os conceitos tradicionais elaborados para descrever a ordem social. A esfera pública não pode ser entendida como uma instituição, nem como uma organização, pois, ela não constitui uma estrutura normativa capaz de diferenciar entre competências e papéis, nem regular o modo de presença a uma organização, etc. Tampouco ela constitui um sistema, pois, mesmo que seja possível delinear seus limites internos, exteriormente ela se caracteriza através de horizontes abertos, permeáveis e deslocáveis.

A esfera pública pode ser descrita como uma rede adequada para a comunicação de conteúdos, tomadas de posição e opiniões; nela os fluxos comunicacionais são filtrados e sintetizados, a ponto de se condensarem em opiniões públicas enfaixadas em temas específicos (Habermas, 2011, p. 92-93).

A esfera pública, como espaço público definido, funciona como estrutura viva para a deliberação no contexto democrático, pois, permite o fluxo dos argumentos desenvolvidos na sociedade até alcançar o centro da administração pública e do sistema jurídico (ANDREWS, 2011, p. 113).

É na esfera pública que a linguagem é filtrada e ocorre a síntese dos argumentos gerados, tendo como aporte máximo a linguagem, para se transfigurarem em opiniões relevantes e de interesse social.

Mas há de se ter um mecanismo para que as vozes, pode-se dizer não organizadas da sociedade civil, cheguem em perspectiva organizada, procedimentalmente, na cúpula parlamentar ou na Administração.

A esfera pública, como ambiente dinâmico de problematizações, ganha espaço e se propaga por intermédio do agir da fala ou, mais especificamente, pelo agir comunicativo. Por sua vez, a linguagem é aquela de compreensão geral e fluida no cotidiano, funcionando como medium comunicacional ativo entre os falantes no mundo da vida. Dessa forma, tanto nas práticas rotineiras da vida quanto nas elucubrações mais elaboradas, especializadas, como a filosofia e o direito, por exemplo, o instrumento será o mesmo, a linguagem (HABERMAS, 2011 p. 320).

Entretanto, a esfera pública não vai se ocupar de nenhuma das duas classificações provenientes da linguagem, as práticas rotineiras e as conjecturas mais profundas, conforme indicada acima. "Por isso quando abrange questões politicamente relevantes, ela deixa ao cargo do sistema político a elaboração especializada" (HABERMAS, 2011, p. 93).

A esfera pública se perfaz de condutas da comunicação, porém tais condutas precisam ser relevantes para o panorama social, sendo necessária, então, uma estrutura especializada, preocupada em ordenar um consenso para gerir o problema posto. Dessa forma, a esfera pública não vai se deter em regular a linguagem coloquial, natural para a comunicação do quotidiano. 
Do ponto de vista do modelo Administrativo de gestão pública encaixa-se também a ideia de Habermas sobre a circulação comunicacional, pois " [...] prioriza a institucionalização de procedimentos democráticos no âmbito interno dos estamentos oficiais e públicos, principalmente os parlamentares [...]" com o objetivo de converter o poder comunicativo em poder administrativo, através da lei e da participação dos cidadãos na institucionalização de procedimentos de conteúdo democrático-deliberativo ou por meio dos debates promovidos na esfera pública (GOÉS, 2013, p. 105), formado o cidadão para o papel participativo no debate público e de autolegislador.

A autolegislação parte da ideia de que o cidadão, além de ser sujeito submisso aos imperativos legais, deva ser também agente formulador dessas mesmas regras, ou seja, deve haver a compreensão de cidadania no aspecto mais largo: o homem capaz de se entender como agente criador de normas e de argumentos fortes para sugerir escolhas administraticas.

Sobre essa mesma temática, a autolegislação de civis para Habermas carece de uma conformação, daqueles que estão dominados pelas regras do direito, como destinatário dos seus comandos, possam compreender-se também como construtores desse mesmo direito. “[...] E, para fazer jus a esta ideia, não basta compreender o direito a iguais liberdades de ação subjetivas como um direito fundamentado moralmente, que necessita apenas da positivação através do legislador político (HABERMAS, 2010, p. 157). A autolegislação necessita da conformação do cidadão com o direito posto e conformação do cidadão com o processo de produção do seu próprio regramento, em atenção aos postulados democrático e de soberania popular, apreendidos no contorno deliberativo, o qual, representa o modelo que possibilita a abertura social para a discussão de questões políticas e administrativas.

O que Habermas também propõe para à Administração é a administração também pautada na dialeticidade, afim de conferir democratização do espaço pertencente à gestão pública (ROCHA, 2008, p. 183.)

É possível, consoante o autor sob análise, a inclusão da pauta lapidada na esfera pública, pela "periferia", no Poder Administrativo, sob o procedimentalismo que preferiu denominar de "Teoria da Eclusa".

A "Teoria da Eclusa" será relida em tópico próprio do presente trabalho e confrontada com as "Assembleias Primárias" de Condorcer pela importância da dinâmica que a deliberação oferece para politizar as pessoas do dever cívico de participar e exercer alguma influência na condução do gerenciamento administrativo do seu Estado/país ou, simplesmente do território onde vivi. 
No entanto, faz-se importante avaliar o procedimentalismo empregado pelo Decreto de participação Social por configurar, no Brasil, um ponto inicial de estudo sobre a dialeticidade na Administração Pública, muito embora seja apontada como mecanismo de manobra política.

Cabe ressaltar que a análise do referido Decreto tem o objetivo acadêmico de leitura política e participação democrática.

\section{O PROPÓSITO DE ATUAÇÃO CONJUNTA ENTRE A SOCIEDADE E AS INSTITUIÇÕES DEMOCRÁTICAS A PARTIR DO PODER EXECUTIVO}

No dia 25 de maio de 2014 foi publicado no Diário Oficial da União o Decreto $\mathrm{n}^{\circ}$ 8.243, implementando a Política Nacional de Participação Social - PNPS, com o propósito de abrir um canal de diálogo e atuação conjunta da sociedade com o governo federal. A pauta do decreto trouxe divergências no cenário político e vários assuntos polêmicos foram levantados, entre eles a legitimidade e criação dos conselhos, o conceito de sociedade civil e a invasão na esfera de competência do Poder Legislativo.

Ademais, o referido decreto sofreu diversos ataques quanto ao seu conteúdo e, pouco tempo depois, o ato normativo foi sustado por meio do Projeto de Decreto Legislativo $\mathrm{n}^{\circ}$ 1491/2014 da Câmara dos Deputados. Entretanto, tal sustação não é o bastante para a sua suspensão total, de modo que, para o Decreto $\mathrm{n}^{\circ} 8.243$ ser retirado por completo do mundo jurídico é preciso também a atuação do Senado. E, nessa direção, o Decreto sobre a Participação Social encontra-se ainda para deliberação dos senadores, denominado sob a sigla SF PDS $117 / 2014$

Propõe-se neste ponto a análise teórica do Decreto, à luz das concepções habermasianas, da Teoria do Discurso e da integralização do cidadão nas temáticas da vida política. Noutro quadrante, o fato de existir críticas quanto a ser o Decreto uma forma de arregimentar e fortalecer grupos vinculados ao Partido dos Trabalhadores não pode ser ignorado, tendo em vista os acontecimentos envolvendo o partido em uma rede de escândalos e corrupção, consoante já mencionado nesse trabalho.

Sobre o tema, Reinaldo Azevedo manifestou seu sentimento em relação ao Decreto que trata da participação elucidando que se trata de um sistema de implantação de conselhos populares, cujos integrantes advém dos movimentos sociais com ligação direta aos órgãos públicos, em uma forma de contemplar a participação dos membros da sociedade civil na 
Administração Pública. "Porém, ao trazer uma definição restritiva de sociedade civil, representa um assombroso ataque à democracia representativa e à igualdade dos cidadãos ao privilegiar grupos alinhados ao governo" (AZEVEDO, 2014).

No entanto, apesar de ser um argumento temerário com possíveis acontecimentos, tal conjuntura não será explorada pois o campo da hipotética deturpação dos fins não está presente na apreciação do decreto em debate e nem a conformação ou não do mesmo com os postulados deliberativos propostos por Habermas. Com esse foco, será analisado o conteúdo do decreto em seus aspectos mais relevantes, assim como os argumentos do Projeto de Decreto Legislativo no $1491 / 2014$.

O Decreto de Participação Social, como é exposto legalmente, tem por missão instituir uma política mais democrática no que se refere à participação popular e às medidas adotadas pela Administração federal, declarando em seu texto que o seu objetivo é "fortalecer e articular os mecanismos e as instâncias democráticas de diálogos e a atuação conjunta entre a administração pública federal e a sociedade civil”.

Já o Decreto Legislativo no 149/2014 que, na órbita da Câmara dos Deputados, sustou o Decreto Presidencial $n^{\circ} 8.243 / 2014$, anuncia em seu texto que os argumentos presidenciais são eivados de inconstitucionalidade uma vez que "corrói as entranhas do regime representativo", ampliando de maneira drástica os mecanismos de controle social para captar e arregimentar grupos ligados ao governo central, além de refutar o cidadão ao segundo plano no cenário da participação.

Quanto ao caráter da inconstitucionalidade vinculado ao argumento de que foge à competência presidencial para expedir ato no sentido do Decreto 8.243/2014, o art. 84, inciso VI, alínea "a", da Constituição Federal informa que é competência privativa do Presidente da República fazer uso de Decreto para coordenar a organização e funcionamento da administração federal, quando tal estruturação não importar no aumento de despesas e tampouco culminar com a criação ou extinção de órgãos públicos. O alcance e limite do dispositivo constitucional em destaque, destarte, é o aumento de despesas e a criação ou extinção de órgãos públicos.

Assim, se o Decreto de Participação não cria e nem extingue nenhum órgão público, apenas reestrutura a Administração Federal para ampliar a possibilidade de participação do cidadão na discussão pública, como forma de desconcentração interna na base se sua estrutura funcional, de modo que não há, nesse ponto, inconstitucionalidade.

Um outro ponto a ser sopesado é a possibilidade do Decreto em questão aumentar as despesas públicas. A despeito disso, o $\S 1^{\circ}$ do artigo 10 do ato sob estudo afirma que "a 
participação dos membros no conselho é considerada prestação de serviço público relevante, não remunerada". E, em assim sendo, também não gera inconstitucionalidade nesse aspecto porque em seu bojo há a previsão expressa da não remuneração.

Mas há ainda outros temas importantes a serem discutidos sobre a Participação Social e um deles diz respeito à sociedade civil. O Decreto da Participação Social considera, no inciso I do artigo $2^{\circ}$, como sociedade civil e o cidadão, tanto individualmente como também grupos colegiados, a exemplo dos movimentos sociais institucionalizados, discriminando o quantitativo dos grupos sociais.

O Decreto da Câmara dos Deputados, responsável pelo primeiro passo da sua sustação, alega que o documento presidencial afasta o cidadão da seara da sociedade civil, incorporando a esta apenas os grupos organizados de representação como os movimentos sociais, por exemplo.

Nesse sentido, serviu como argumento de fundamentação para o Decreto Legislativo o fato do Governo Federal "escolher" o que será considerado sociedade civil ou movimentos sociais, afastando, assim, o cidadão comum do plano político- participativo (BRASIL, DECRETO LEGISLATIVO No 1491/2014). ${ }^{1}$

Necessário então estabelecer algumas ponderações habermasianas sobre sociedade civil.Em Direito e Democracia II, Habermas enaltece que "[...] atualmente o significado

\footnotetext{
${ }^{1} \mathrm{O}$ trecho integral do referido Decreto, tombado sob o número 1491/2014 reza o seguinte: "Nesta primeira etapa, resta patente a prevalência do direito à participação daqueles considerados pelo Governo como sociedade civil ou movimentos sociais, com incentivo à sua formação. O cidadão comum, não afeto a este ativismo social, fica relegado ao segundo plano dentro da organização política prevista no referido Decreto".
} 
da expressão 'sociedade civil' não coincide com o da 'sociedade burguesa', da tradição liberal, que Hegel chegara a tematizar como 'sistema de necessidades'[...]” em nítida economia de mercado. Para Habermas, a sociedade civil vai mais além de um conceito ligado ao mercado de capitais, da economia, como no tempo do marxismo, no qual o trabalho e o capital imperavam nas relações humanas (HABERMAS, 2011, p.100).

Na concepção habermasiana, o núcleo central da sociedade civil "[...] é formado por associações e organizações livres, não estatais e não econômicas, as quais ancoram as estruturas de comunicação da esfera pública nos componentes sociais do mundo da vida [...]" (HABERMAS, 2011, p.100). Nessa linha de raciocínio, a sociedade civil tem o propósito de captar os problemas oriundos da vida privada, a fim de prepará-los para serem levados ao meio político, através dos movimentos, organizações e associações que a constitui.

Em assim sendo, e partindo da visão de Habermas sobre sociedade civil, é possível designar tal sociedade como uma "verdadeira caixa de ressonância" das questões postas pelos cidadãos. A sociedade civil comporta o mundo da vida e é nela que os atores sociais se expressam por meio da linguagem e verbalizam seus problemas, a fim de que esses mesmos problemas possam alcançar o patamar do comando político. E as estruturas aptas ao discurso se configuram em movimentos, organizações e associações (HABERMAS, 2011, p.100).

O cidadão não fica excluído do debate como se pensa, na verdade é conferida a faculdade ao debate, de forma individualizada ou inserido em grupo (os coletivos). $\mathrm{O}$ fato do cidadão não desejar participar não significa seu afastamento nem renúncia a representatividade. Quando se busca o envolvimento político do cidadão com as questões de natureza pública se faz necessário que o homem social se queira como ator politizado de uma sociedade em desenvolvimento e, para isso, é essencial a participação ativa, evidenciada por meio da fala, metodologicamente aplicada.

No contexto da Teoria do Discurso é possível que um único indivíduo ou um grupo minoritário seja capaz de conduzir o dissenso para o consenso, que defende ser o seu argumento for o mais forte, considerando que o debate segue regras pré estabelecidas e que haja oportunidades iguais de falar, sem coação e sem manipulação.

Por esse prisma, o Decreto da Participação Social não segrega o indivíduo do debate público e nem cria conceito novo de sociedade civil, uma vez que todos os elementos indicadores de agrupamentos já se consistem em realidade atuante no Brasil e, naturalmente, fazem parte da sociedade.

Outra crítica apontada pelo decreto legislativo que susta o decreto presidencial da Participação Social é quanto a tornar o Legislativo uma casa vazia ao debate 
institucionalizado, uma vez que o objetivo do Decreto seria destruir o regime democrático representativo ao passo que a tendência é transformar o Parlamento em um "elefante branco" com a transferência do debate para outros ramos da sociedade, arregimentado pelo Governo atual (BRASIL, DECRETO LEGISLATIVO No 1491/2014). ${ }^{2}$

Pelo fragmento de texto citado acima, denota-se a grande preocupação dos deputados federais com a "intenção" por trás do Decreto da Participação Social, ou seja, o receio de que

o Governo Federal se utilize das estruturas de participação social para fazer valer a sua vontade, notadamente perante as questões envolvendo políticas públicas, pois, haveria a "cooptação" do debate para os conselhos, o que, supostamente, levaria a manipulação das vontades para a escolha da decisão que fosse do interesse do governo, acobertado pela legitimação promovida pela participação social.

Outro aspecto, mas ainda decorrente da "cooptação" do debate, é que a comunicação em sede dos mecanismos de participação furtaria do Legislativo o papel de promover o diálogo dos assuntos institucionais, suprimindo sua atuação genuína e mitigando a representatividade.

Nesse aspecto, vale registrar que o sentido de representatividade, hoje adotado pela estrutura política brasileira, foi enaltecido pela Constituição Federal de 1988. Na sua conformação, a Lei Maior proclama um núcleo principiológico estruturante e essencial para a vida do Estado. Esses princípios são os valores pertinentes ao Estado de Direito, à Democracia, à Federação, à República e aos Direitos Fundamentais, sem os quais não se poderia imaginar uma nação livre e democrática.

O contorno da democracia ganha destaque quando confrontada à participação cidadão. O temor dos parlamentares em relação ao Decreto Presidencial nº 8.243/2014, que desvela o envolvimento do cidadão de forma mais profunda nas questões sociais e políticas, releva uma imaturidade democrática e em descompasso com o enunciado constitucional de que "todo poder emana do povo, que o exercerá por meio de representantes eleitos ou

${ }^{2} \mathrm{O}$ fragmento do Decreto descreve, integralmente, a seguinte situação: "Essas breves linhas retratam de maneira absolutamente clara qual a intenção da Presidente da República: implodir o regime de democracia representativa, na medida em que tende a transformar esta Casa em um autêntico elefante branco, mediante a transferência do debate institucional para segmentos eventualmente cooptados pelo próprio Governo. O ato em questão não comporta outra leitura. Especialmente, levando-se em conta que a Carta da República já disponibiliza os instrumentos que asseguram a participação de qualquer cidadão brasileiro nas decisões políticas" (BRASIL, DECRETO LEGISLATIVO No 1491/2014). 
diretamente" e que não se restringe apenas a iniciativa popular, o plebiscito, o referendo e o sufrágio secreto e universal.

Sobre o debate em tela, o professor Filomeno Moraes no seu artigo "Reforma e Pluralismo Político" esclarece sobre o alcance de "todo poder emana do povo". Esse poder é exercido por intermédio dos representantes eleito, considerando o sistema eleitoral, mas também a possibilidade desse mesmo poder ser exercido diretamente, pelo sistema de participação. Se no modelo da representação eleitoral o poder político é uma atividade desempenhada pelos vereadores, prefeitos, deputados estaduais, governadores, deputados federais, senadores e Presidente da República, no modelo participativo as decisões políticas são deliberadas com a atividade direta dos eleitores, a qual "abre a perspectiva de um modelo misto, de democracia semidireta" (MORAES, 2006, p.239).

O grande problema não se perfaz no debate, mas sim na construção do debate como expressão de poder estatal, de modo que a participação direta pode, além de reforçar as diretrizes constitucionais sobre a participação direta, ainda enfraquecer a representação ilusória. O sentido do que está expresso por letras no decreto presidencial sob análise não enfraquece o Parlamento e nem poderia, pois seria inviável sequelar a tripartição dos Poderes, a forma de Estado e o sistema de Governo.

Se há subterfúgios, algo além das bases teóricas da representação, participação popular e democracia no Decreto, precisa ser combatido duramente, mas a princípio não é esse o conteúdo que se extrai da interpretação do ato do Executivo. Importante destacar que Paulo Bonavides sempre se colocou como defensor da democracia participativa, com o foco de colocar o cidadão mais próximo do discurso político, pois, para o professor cearense, a soberania constitucional é a soberania dos princípios, na qual o princípio se sobrepões a regra, e que a determina.

Nesse sentido, "a soberania constitucional é o governo da constituição e não dos juízes, logo, é o primado dos princípios e não dos atos de arbítrio dos órgãos do executivo" (BONAVIDES, 2008, p. 300).

A supremacia é a vontade emanada do povo e está presente em todas as instâncias de poder, mas deve ser usada para impor barreira aos desmandos, a "[...] usurpação de vontade mediada por representantes que arruinaram o antigo poder legítimo das assembleias parlamentares; poder cuja legitimidade, corroída da corrupção, há de soçobrar[...]” se não por compartilhada, no seu exercício pelo povo de forma direta (BONAVIDES, 2008, p. 300).

A participação proposta pelo Decreto Presidencial $n^{\circ}$ 8.243/2014 aproxima-se mais do contato dialógico entre instituições públicas e cidadãos, em uma tentativa de democratização 
do espaço público e, mais especificamente, o Poder Executivo. A administração pública, que se quer firmada no diálogo possui a característica essencial da "intervenção comunicativa".

Nesse sentido, o diálogo deve abrir o canal, ser o fio condutor entre os atores dispostos ao debate, a fim de ampliar a discussão no cenário público, fazendo com que cidadãos, organizações da sociedade civil e gestores públicos possam estudar e deliberar sobre as medidas administrativas que seriam executadas pela Administração Pública, por configurarem como a melhor opção para a sociedade (LIMA, 2013, p. 101).

Essa forma de ampliar a democracia nasce, por assim dizer, do sentimento de segregação imposto pela democracia representativa pura. Não há na democracia representativa o condão real de atender interesses públicos primários.

Segundo Maria Goretti Dal Bosco “[...] a realidade latino-americana demostra que, especialmente nos países pobres, ela não tem sido eficiente para garantir direitos fundamentais e sociais das populações [...]", entretanto é o melhor sistema de governo, inclusive na América Latina, onde há democracias ainda em construção, mas não mais mantém laços com os ideais gregos e nem apresenta aspectos das democracias aplicadas em nações em desenvolvimento (DAL BOSCO, 2008, p. 95).

A intenção aqui não é submeter todas as decisões de governo ao diálogo popular, mas sim de ampliar o espaço democrático para uma atuação administrativa aproximada do interesse público. A conduta dialógica permite não apenas o debate de questões importantes para a sociedade mais também confere uma fiscalização maior na condução da coisa pública.

Perto do debate está o povo, mas como figura apática de manipulação para garantir a estabilidade legitimadora do Sistema político representativista, e não como agente de atuação e elemento essencial da democracia.

Aliás, Friedrich Müller já lanchou o assunto da tensão entre democracia e participação democrática no contexto da soberania popular. Para o autor alemão, o povo, apesar de ser a estrutura principal da democracia, ainda carece de reflexão, sobre o seu papel na política.

Nessa linha de raciocínio José Luis Bolzan de Morais enfatiza que o problema que cerca a democracia é a questão da legitimação popular e os mecanismos utilizados para mantê-la, em um espaço no qual os modelos utilizados são corroídos, notadamente, o modelo de representação popular “[...] seja diante das insuficiências do próprio modelo, seja diante do influxo do processo de colonização da política pelas determinações econômicas globais que caracteriza esse modelo 'neo' moderno" (MORAIS, 2006, p. 115). ${ }^{3}$ 
Morais, além de realizar estudo sobre "quem é o povo", sob a ótica de Müller, indaga “onde está o povo", convocando a necessidade de reconstrução de espaços democráticos, sob pena do elemento povo diluir-se “[...] na massificação de uma falsa democracia midiática da qual temos tido, nestes dias atuais (2005), uma triste experiência” (MÜLLER, 2000, p.55).

Para o autor, a solução para se "modernizar" o modelo arcaico da representatividade, insuflado pela crise política, é a estratégia que contempla a participação direta, sob o manto da representação ou na atividade participativa para, consoante Morais, ser capaz de transpassar "esse momento neofeodal".

A represetação, analisada sob uma visão ampla, deve ser capaz de captar as vozes provenientes da arena discursiva dos espaços públicos para, de fato, ser possível identificar o povo no circuíto político, em verdadeira harmonia com a diretriz da deliberação democrática, o que vai além da representação pura.

\section{A QUESTÃo da VINCULAÇÃo do GESTOR PÚblico AO CONSENSO ADVINDO DA DISCUSSÃO NA ESFERA PÚBLICA}

Em face do que foi até aqui examinado, resta aludir a questão da vinculação, ou seja, se o administrador público ficaria adstrito à vontade oriunda do debate realizado em nível de conselhos ou de núcleos representativos do discurso e do consenso. Para avaliar a amplitude da decisão tomada de forma discursiva, dialógica, e a sua influência no Poder Executivo, a tese de dois autores, especificamente, serão o ponto de apoio, Jürgen Habermas e Marie Jean Antoine Nicolas, o marquês de Condorcet.

Condorcet e Habermas apresentam semelhanças em seus planos de inclusão cidadã como forma de concretização da democracia ampla, aquela pautada na oportunidade de deliberação dialógica entre os atores sociais e amparada pelo procedimento normativo. Entretanto, irão divergir quanto ao atingimento ou influência que o trato dialógico, obtido da discussão pública de assuntos político-sociais, tem na esfera do Poder Público.

\footnotetext{
${ }^{3}$ O termo "neo" utilizado pelo autor representa uma nova forma de abordagens a modelos antigos ou tradicionais. Não seria um novo no sentido de primeira aparição, mas sim com a conotação de uma nova roupagem.
} 
XVIII e, apesar de seus textos serem objeto de poucos estudos no Brasil, a sua teoria significa uma perspectiva peculiar de se pensar teorias políticas e democracia. Segundo

Cristina Foroni Consani, Condorcet “[...] dedicou-se simultaneamente à teoria e à prática política, tendo escrito tratados de caráter científico e também projetos específicos para a república Francesa pós-revolução" (CONSANI, 2010, p. 59-75).

Jean-Antoine-Nicolas de Caritat foi também entusiasta dos propósitos da Revolução Americana de 1776 e participou ativamente da Revolução Francesa de 1789, sendo membro deputado da Assembleia Legislativa em 1791 e, em 1792, participando da Convenção Nacional. Em 1793, Condorcet escreve aos cidadãos franceses em crítica à (nova) Constituição adotada, pois, o Projeto de Constituição defendido por Condocert, Paine e outros, fora rejeitado na Convenção Nacional o que, para ele, representou posicionamentos de retrocesso político e social e a afirmação da vontade da aristocracia.

Segundo Condorcet, a nova Constituição designava o povo de forma inversamente oposta aos ideais da Revolução, sendo considerado no novo texto constitucional como povo “[...] os homens corrompidos ou extraviados que eles reúnem em grupos, que eles amontoam nas tribunas; mas o povo soberano em suas Assembleias Primárias é para ele um juiz terrível que eles odeiam porque o temem." (CONDORCET, 2013, p. 195).

Muito embora o projeto constitucional encabeçado por Condorcet tenha sido recusado, o seu conteúdo é predominantemente democrático, em especial com a elaboração das Assembleias Primárias, ambiente esquematizado para servir ao debate e que não faz restrição a qualquer cidadão, pois todos tinham o dever de participar dos contornos políticos. Por essa razão, a teoria do revolucionário em tela será estudada e alinhada à Teoria Deliberativa habermasiana.

Condorcet acreditava em uma ordem política na qual os direitos políticos pudessem ser estendidos a todas as pessoas de forma igualitária, diferentemente do que se observava à sua época, oportunidade em que a participação política era determinada pela renda, por exemplo.

Na França de 1788 e na maior parte das sociedades desse período, a democracia se baseava na representação, na qual os representantes eram escolhidos por um número limitado de cidadãos, pois nem todos exerciam direitos políticos. Condorcet entendia que havia restrição ao exercício dos direitos políticos impostos aos cidadãos e que essas mesmas pessoas “[...] acreditaram poder confiar a uma parcela dos cidadãos a representação dos direitos de todos. O poder conferido a esse pequeno grupo seria exercido em nome do interesse geral da 
sociedade [...]" e por esse motivo se pensava que condutas ilícitas, como os excessos decorrentes dos abusos e dos desvios não seriam praticados (CONSANI, 2010, p. 59-75).

Inversamente ao que era aplicado "democraticamente" como direitos políticos, Condorcet era um ferrenho defensor dos ideais de participação plena. Não concordava que parte da população fosse descartada do processo político e que também a participação, assim considerada, fosse dividida - um grupo restrito escolhe e o escolhido governa (CONSANI, 2010, p. 59-75).

Nadia Urbinat, em estudo sobre o que torna a representação democrática, avalia a teoria proposta por Condorcet e Paine. E afirma que desde o século XVIII tais teóricos “[...] propuseram situar a representação dentro de um misto complexo de deliberação e voto, autorização formal e influência informal, que envolve tanto representantes quanto cidadãos. Em vez de um esquema de delegação da soberania [...]” (URBINATI, 2000, p. 191-228).

Condorcet, assim como Paine, tinham uma visão além da estrutura de democracia e participação política conhecidas no seu tempo. O ponto central do pensamento vanguardista dos democratas é conceber a representação sem separar sociedade e instituições e sim, de encará-la como instrumento, decorrente de um processo político, que seja capaz de unir o corpo social e as instituições.

E, refletindo acerca dos argumentos de Condorcet e Paine, Urbinati, repensa a democracia representativa. Para a autora, um conceito moderno, do modelo de representação que temos hoje, precisa unir uma concepção mais atualizada de soberania popular "[...] que conteste o monopólio da vontade na definição e na prática da liberdade política. Ela marca o fim da política do sim ou não e o início da política como uma arena de opiniões contestáveis e decisões sujeitas à revisão a qualquer tempo" (URBINATI, 2000, p. 191-228). Tal proposição reafirma a necessidade de ampliar a participação cidadã e o próprio sentido da presença dos atores no espaço político, refletindo e repassando as vozes oriundas do discurso acerca das leis e opções políticas, sob o manto do justo e injusto, em atitude consciente e ativa do dever de inteiração política.

A postura argumentativa de Urbinati revela a preocupação em trilhar um caminho moderno de participação, além do momento único da escolha dos representantes, lastreada na discursividade entre os cidadãos e entre estes e as Instituições, retomando, para essa construção, a forma de participação já delineada na visão de Condorcet e de Habermas, que é a implementação do debate para a construção da democracia, a qual se denomina de participativa, mas que contém fundamentação na linguagem, a fim de que o cidadão exerça a soberania de maneira politizada e procedimentalista. 
Noutro pórtico, entende Condorcet que a participação cidadã num contexto democrático pressupõe a capacitação dos atores sociais, de modo que é a partir da educação que se estabelecem as bases da emancipação das pessoas, as quais deixam cair o véu da ignorância e passam a compreender a complexidade das relações sociais e as consequências das decisões sociopolítico-econômicas a serem tomadas.

Nesse sentido, “[...] Condorcet vincula a instrução pública à soberania popular, nos quadros de uma república laica, erguida sobre o sufrágio universal e o exercício da administração pelo povo instruído [...]" (PIOZZI, 2004, p. 655-676).

Condorcet não segrega a educação, a política e a democracia como conceitos herméticos e dissociáveis. Na sua visão, esses três elementos devem comungar para a formação da "esfera pública esclarecida”. Assim, “[...] é necessário, por tanto, ao mesmo tempo, que um dos degraus da instrução comum habilite os homens de uma capacidade ordinária, a aprender as funções públicas [...]" (CONDORCET, 1994, p. 78).

A questão da soberania popular, participação e democracia são elos bastante fortes na concepção de Condorcet, na qual o amálgama essencial é a educação e, nesse sentido, vale a pena repisar que essas noções em muito se aproximam da filosofia política defendida por Thomas Jefferson, notadamente no tema que envolve a soberania popular e autogoverno, uma vez que o republicano norte-americano defende a participação direta nas questões de ordem local e a educação pública como meio necessário para galgar o caminho da politização. E, nesse aspecto, também compartilham de uma mesma opinião, uma vez que para Condorcet acreditava que "[...] a desigualdade de instrução pode ser combatida com a instituição da instrução pública elementar, universal e gratuita [...]" (CONSANI; KLEIN, 2014, p. 111-131).

Entretanto, para Jefferson o termo cidadão era limitado a uma classe mais abastarda e privilegiada, designada pelo sexo masculino, cor da pele e renda. Ao contrário, Condorcet acreditava na igualdade na ordem natural, na igualdade relacionada ao gozo de direitos e, sobretudo, na igualdade política para todas as pessoas, independente do sexo, cor e renda.

Condorcet era defensor de liberdades e, em seus escritos sobre política e sociedade nos moldes republicanos, o autor acreditava que, para se concretizar um Estado Democrático (pósRevolução Francesa - 1789) era indispensável promover a liberdade de imprensa, do comércio, das mulheres, dos negros, dos judeus e implementar uma instrução universalizante, pois, o que distinguiria os homens em sociedade seria o grau de instrução ${ }^{4}$ e não o genótipo ou fenótipo do indivíduo (CONDORCET, 1994, p. 9). 
Assim, “[...] o autor entende que os direitos políticos devem ser estendidos a todos os cidadãos, independentemente de sua condição socioeconômica, de raça ou nacionalidade, submetidos apenas às condições gerais estipuladas pela Constituição" (CONDORCET, 1994, p. 13).

A Revolução Francesa marca a história mundial, mas não só do aspecto da mudança de paradigma da monarquia para o republicanismo de ideais. A Revolução não foi apenas um marco da reconstrução nacional com base em linhas democráticas. Além disso, marcou os rumos do liame que há entre educação e política, sob o prisma de que o novo legado, de inspiração democrática, só poderia resistir e ser viável se a educação fosse vislumbrada como algo essencial e necessário para o progresso e consolidação do sistema político pós- Revolução.

Seria preciso uma revolução na educação e, nessa seara, Condorcet foi um dos idealizadores da construção da instrução pública como pilar democrático e formadora de cidadão, indistintamente considerados, conscientes com seus deveres políticos.

Visionário, Condorcet acreditava que o projeto educacional possuía o poder de emancipar o cidadão, dando-lhe condições de libertar sua consciência sem a necessidade de submeter suas aspirações à razão de outro. Caberia então, aos poderes criarem condições para, por meio do processo pedagógico, fomentar a razão autônoma, a igualdade e a superação do talento individual sobre a riqueza (BOTO, 2003, p. 735-762). Mas, retomando a proposta de Condorcet de vocalização dos interesses públicos, cabe, por oportuno, expor as diretrizes da igualdade política que, consoante o marquês "[...] consiste no exercício dos direitos políticos e na participação na soberania nacional [...]”, a qual é lapidada no bojo de um projeto de constituição para que o cidadão tenha a oportunidade de participar do processo legislativo, fazendo com que a vontade das pessoas esteja presente no conteúdo legal, o qual se submete (CONSANI; KLEIN, 2014, p. 111-131).

\footnotetext{
${ }^{4}$ Condorcet acreditava na instrução pública, assim como Jefferson, essencial para o desenvolvimento do indivíduo, que poderia, no contexto de suas aptidões, se engajar nos diversos tipos de ofícios, tendo, em tese, as mesmas chances que os demais, pois recebeu do Estado a mesma qualidade de instrução, de educação. Entretanto, é importante mencionar que, para Condorcet, apesar da educação pública ser um objetivo a ser perseguido e alcançada na República, não é determinante para a obtenção de direitos políticos. Para o autor, o exercício dos direitos de cidadão, inclusive os políticos, era necessário ter 21 anos e se inscrever em uma Assembleia primária e, mesmo aquele que não seja cidadão francês por nascimento, mas tenha residido por um ano initerruptamente na França, é cidadão da República francesa, consoante o Artigo primeiro do Título II do Projeto de Constituição Francesa.
} 
Condorcet não idealizou a participação direta, mas sim mecanismos de trazer o cidadão para mais próximo do exercício deliberativo da democracia e da soberania popular, no qual as vozes sociais repercutissem e firmassem posição nas decisões públicas tomadas pelos gestores públicos.

Em seus planos, concretizou regras capazes de impor limites a atuação pública das pessoas como forma de conservar o interesse comum. Desse modo, percebe-se que "[...] sua meta foi 'prevenir a participação 'imprudente' pelos cidadãos ou por seus representantes, expostos à ignorância, a interesses sectários e à intemperança das paixões"”. E, com a missão de prevenir tais problemas, Condorcet especificou, no projeto de constituição um número maior de locais para o debate e também o alargamento de tempo a adoção de medidas (CONSANI; KLEIN, 2014, p. 111-131).

Sobre o tema, o texto do "Projeto de Constituição Francesa", encabeçado por Condorcet, traz no Título primeiro o delineamento da divisão do território e estabelece que a França é una e indivisível e dividida em departamentos (85), sendo que “[...] cada departamento será dividido em grandes comunas; as comunas em seções municipais e em Assembleias Primárias (Título Primeiro, Artigo Primeiro, II e IV) (CONDORCET, 2013, p. 130).

As Assembleias Primárias eram o local onde os franceses tinham o dever de exercitar os seus direitos de cidadãos, mais especificamente seus direitos políticos. Tais assembleias foram intuídas no projeto para serem distribuídas sobre todo o território francês de cada departamento. A estrutura política desenhada por Condorcet destacava o cidadão como ser participativo da vida Republicana e Democrática, pois era um dever cívico reunir-se para deliberar e participar da dinâmica política e social do pois.

Os argumentos obtidos na esfera pública do debate, regido por um procedimento normativo prévio eram base para a hermenêutica dos problemas levantados e da fundamentação legislativa ou executiva para a construção da lei ou para a execução de uma atividade de competência administrativa.

Sob esse ângulo, é preciso destacar a tarefa do cidadão frente à Constituição, pois, no projeto que reconhece o debate público como viés democrático de gestão, cabia ao cidadão francês reunir-se nas Assembleias Primarias para participar das eleições determinadas pela Constituição; para deliberarem acerca de temas de interesse geral da República, como: aceitação ou recursa de projeto de Constituição ou uma modificação, seja essa alteração qualquer que seja, quando se propõe a convocação de uma Convenção Nacional, quando o Legislativo tem 
que se pronunciar sobre assunto que diz respeito à república inteira e quando se requer que o Corpo Legislativo leve em consideração quando de exercer sobre os atos da representação nacional a censura do povo, consoante o regramento fixado pela Constituição (CONDORCET, 2013, p. 134).

A estrutura do modelo delineado por Condorcet sobre os vários espaços de debate oferece um precedente importante para a deliberação: a divisão do território nacional. Nesse sentido, o funcionamento dessa divisão é explicado por Consani e Klein da seguinte maneira:

\begin{abstract}
A proposta era de que o território fosse dividido de forma a proporcionar a maior participação possível dos cidadãos em pequenas instâncias deliberativas. A nação distribuiria seu poder político decisório em departamentos, comunas, seções municipais e estas seriam subdivididas em assembleias primárias. As assembleias primárias eram lugares físicos onde qualquer cidadão poderia consultar boletins sobre a atividade legislativa da assembleia nacional, apresentar sua proposta de emenda a uma lei existente e submetê-la à discussão e ao voto, votar em propostas vindas de outras assembleias ou simplesmente selecionar candidatos e eleger representantes, assim como solicitar a perda do cargo de um representante eleito. Condorcet vislumbrou na institucionalização desses canais de diálogo com os cidadãos uma forma de evitar revoltas, facções e manifestações desordenadas. Nesse aspecto, sua teoria política deixa como legado a possibilidade de conciliação do sistema representativo com a participação popular. (CONSANI; KLEIN, 2014, p. 111-
\end{abstract} 131).

Outro ponto relevante e digno de ser repisado é o fato de que se todas as Assembleias Primárias forem chamadas a deliberar sobre o mesmo tema, o resultado geral das conclusões extraídas dos debates entre os pares, de cada departamento, será encaminhado ao Corpo Legislativo, por meio das suas administrações específicas, para que o Legislativo constate e publique o resultado geral da resolução dos cidadãos, contido no tópico sobre Formas das Deliberações nas Assembleias Primárias - Título II, Seção V, IX (CONDORCET, 2013, p. 141).

Os escritos em análise também têm outra característica marcante, a saber: a necessidade de fiscalização contundente do cidadão, “[...] a possibilidade do exercício de um controle dos cidadãos sobre seus representantes durante a vigência de seus mandatos [...]" (CONSANI; KLEIN, 2014, p. 111-131), podendo, consoante o projeto intentado por Condorcet, os cidadãos resistirem a uma lei injusta, muito embora decorrente do Poder legítimo. Assim, a perspectiva democrática da deliberação de Condorcet encontra no procedimento legal e regulamentado, a fundamentação para que o papel do cidadão seja ampliado em todo o território nacional.

A divisão geográfica tem a missão de permitir a participação política do corpo social, o qual não fica preso a um tempo determinado de debates e nem reduzido a um único espaço. 
Dessa forma, o cidadão, no exercício dos seus direitos, é apto, a partir das discussões nas Assembleias Primárias, a influenciar os rumos políticos e, além disso, ser agente fiscalizador dos representantes, coibindo, dessa forma a corrupção e os desvios na administração.

Por outro lado, a deliberação de orientação habermasiana, cujo pensamento é publicitado na década de 80, ganha outro contorno, com a reanálise de Habermas sobre sistema e mundo da vida. Assim, foi necessário criar um projeto que pudesse imprimir força a instituição de forma que ela pudesse receber, continuamente, os fluxos e influxos do mundo da vida. É assim que Habermas reformula a relação existente na esfera pública para encaixá-la no contexto do sistema denominado de "eclusas". Em dois trabalhos de Habermas é possível sentir a mudança do seu pensamento sobre esfera pública. Em Theorie des kommunikativen Handelns, o autor enfatiza a esfera pública como cenário de atuação para o mundo da vida, com o compromisso de zelar por sua autonomia em face do sistema administrado, com conotação de esfera "defensiva", cuja preocupação maior era sitiar o sistema, mas sem interesse em influenciá-lo. Em Faktizität und Geltung, a esfera pública recebe um expoente mais "ofensivo", posto que a mudança ideológica consiste em ignorar o aspecto defensivo do sitiamento sistêmico e implementar uma atuação mais contumaz, ativa, ofensiva da esfera pública com a proposta das "eclusas", modificando, assim, a percepção da esfera pública (UBENOW, 2010, p. 227-258).

E é, justamente, sob a nomenclatura de "eclusa", já mencionada que o mundo da vida incorpora mais força para estabelecer o diálogo com as Instituições. Apenas para relembrar, Habermas explica a teoria da eclusa para demonstrar a forma com que camadas periféricas podem fazer valer seu discurso de interesse frente ao poder executivo. Assim, a sociedade civil coordena demanda de interesses peculiares e capitaneia forças em outros grupos para que possam exercer pressão e influência naqueles que têm a tarefa de decidir, de modo que o sentido da "eclusa" seria o de represar um volume de vozes para que as pautas estabelecidas saiam da periferia e atinjam o centro das decisões.

No entanto, cabe identificar a diferença maior entre Condorcet e Habermas quanto ao modo de influência que a comunicação entre o mundo da vida, ou o diálogo construído a partir das assembleias exerce sobre as instituições, especificamente, sobre o Poder Executivo.

Segundo Habermas, o fluxo comunicacional periférico alcança o Poder Central e retorna à sociedade, para que esse processo de construção eloquente dos interesses sociais não venha a se imiscuir no sistema, pois dele não faz parte. Assim, precisam, de fato, coexistirem e se coordenarem nas vontades, mas não se trata do mesmo corpo, por essa razão, deve a 
periferia retornar ao mundo da vida e nele se renovar em vontades, consoante a dinâmica natural das pluralidades existente em sociedade, gerando um novo modo de circulação de poder.

Para Habermas, forma-se a seguinte estrutura para a Administração:

[...]nas margens da administração forma-se uma espécie de periferia interna, que abrange instituições variadas, dotadas de tipos diferentes de direitos de autoadministração ou de funções estatais delegadas, de controle ou de soberania (universidades, sistemas de seguros, representações de corporações, câmaras, associações beneficentes, fundações, etc.). Tomado em seu conjunto, o núcleo possui uma periferia exterior, a qual se bifurca, grosso modo, em compradores $e$ fornecedores (HABERMAS, 1992, p. 430).

Entretanto, a vontade da periferia, estabelecida por meio de uma organização própria, alcança o processo formal da instituição, mas não determina que o Poder Público atuará no sentido pleiteado pelo corpo social (periferia). O administrador, nesse caso, é perfeitamente livre para, dentro dos parâmetros da discricionariedade e legalidade, atender ou não a pauta da periferia. Contudo, deverá ficar obrigado a motivar as razões do seu convencimento, tanto para acatar como para rejeitar, de modo que a essas razões não fica vinculado.

Por outro lado, o projeto de Constituição de Condorcet admite uma interferência direta da vontade dos cidadãos na Esfera Política. Através das Assembleias Primárias os cidadãos podem se reunir, como um dever cívico de participação na vida pública da cidade, e através dos procedimentos adotados para os debates e escolhas públicas, elegerem o que a comunidade considera para oportuno naquele momento.

É certo que essa vontade, uma vez concretizada em uma instância, pode unir-se as outras vontades, de outros departamentos e Assembleias, e somarem forças para persuadir ao Poder Central a adotar a medida pactuada e confirmada nos conselhos.

A ideia de Condorcet também consiste em criar no cidadão o dever de ser um homem politizado, agente ativo no rumo político de escolhas e decisões da nação, além de apregoar que seria a melhor forma de controlar a corrupção, pois a sociedade estaria imbuída do espírito de vigília com os assuntos de interesses da comunidade.

Condorcet, assim como Habermas, se alinha ao procedimentalismo deliberativo para atingir uma escala democrática na qual as vozes dos atores sociais possam ser ouvidas pelos poderes Públicos, em sintonia com o princípio maior da soberania popular.

\section{CONSIDERAÇÕES FINAIS}


A aplicação da Democracia Deliberativa na Administração Pública mostra-se como elo de aproximação entre a relação mais substancial da nação, qual seja, entre o povo e o Estado, no sentido de que as vozes sociais sejam ouvidas e discutidas no cenário público com o objetivo de provocar uma análise mais apurada dos problemas e necessidades gerais.

Habermas desenvolve a partir do Agir Comunicativo o Discurso Democrático também para o Poder Administrativo, mas pautado no procedimentalismo, ou seja, na institucionalização de regras que possam propiciar o debate democrático.

No Brasil, o Decreto n. ${ }^{\circ} 8.243 / 2014$ criou um mecanismo procedimentalizado de participação social na administração pública federal, elaborando para tal desiderato modalidades de inteiração social como conselhos, audiência, ambiente virtual e outros.

Apesar das inúmeras críticas ao Decreto apontado, o fato é que o mesmo apresenta, indiscutivelmente, critérios procedimentalizados para a atuação do cidadão no espaço político.

A deliberação é o caminho natural para o avanço democrático, entretanto, no Brasil, a procedimentalização do regramento pertinente ao debate deve estar vinculado a um pressuposto primeiro de atuação pública: o fortalecimento de valores morais, tanto individuais quanto coletivo.

A crise política e o desregramento das Instituições públicas, no caso concreto das Administrações Públicas, está diretamente ligada a falta de compromisso moral com o desempenho das funções do Estado. Os gestores públicos vivem mais por uma vontade individua, particular ou setorizada do que a vontade geral, ligada as necessidades básicas da população.

Por outro lado, a população também sofre do mal da ausência da moral, e esse comportamento individual se reflete nas pequenas ações do dia a dia, como estacionar o carro em vagas destinadas aos deficientes físicos e ao eleger políticos notoriamente envolvidos em casos de corrupção, por exemplo.

A deliberação compreende regrar fortes de ética para a obtenção do discurso mais coerente para atender as carências públicas. Nesse sentido, é possível perquirir qual o parâmetro de honestidade, de moral pública para a correta condução da coisa pública que os brasileiros tomam como a de melhor opção. A maturidade de um povo, o desejo de se politizar o homem para que ele se torne um membro proativo na deliberação Administrativa passa, antes do procedimentalismo, pela formação moral e educacional que possam vencer o agir estratégico. 
Ainda estamos caminhando rumo aos espaços democráticos, ou melhor, ainda estamos querendo entender o funcionamento de uma democracia avançada, alicerçada na deliberação, mas, de novo, outro cuidado deve ser tomado, para que os núcleos de discussão não se transformem em núcleos de representação e, sob esse argumento é que as questões adotadas na esfera pública não podem ter força vinculante para o administrador, pois, dessa forma, estar-se-ia respeitando a separação e a autonomia dos poderes, o republicanismo e a soberania popular.

O administrador receberia o fluxo do consenso discutido na periferia e, na tomada de decisão teria a obrigação de fundamentar pontualmente as razões pelo acatamento ou não, favorecendo a maior fiscalização dos seus atos pelo Ministério Público, Tribunais de Contas e pela própria sociedade civil atuante e inteirada dos acontecimentos políticos. Em verdade, a deliberação democrática, aplicada à Administração Pública, tem o aporte de proceder ao controle mais direcionado. A fiscalização a partir da participação ampla, deliberativa, teria a finalidade de controlar a aplicação dos recursos públicos e direcionar melhor as opções políticas, voltadas para as reais convicções públicas.

A democracia dialética na gestão pública deve ser realizada pautada no procedimentalismo e ter, como pressuposto necessário para sua aplicação uma população educada para empreender os valores deliberativos, ou seja, cidadãos aptos para se envolverem na estrutura política e também conscientes do seu dever como integrante social, politizado. Outro valor a ser percebido como primordial é o moral, matriz para a formação de nações mais desenvolvidas. 


\section{REFERENCIAS}

ANDREWS, Cristina W. Emancipação e legitimidade: uma introdução à obra de Jürgen Habermas. São Paulo: Unifesp, 2011.

BONAVIDES, Paulo. Teoria Constitucional da Democracia Participativa. Por um Direito Constitucional de luta e resistência por uma Nova Hermenêutica por uma repolitização da legitimidade. São Paulo: Malheiros, 2008.

BOTO, Carlota. Na Revolução Francesa, os princípios democráticos da escola pública, laica e gratuita: o relatório de Condorcet. Educação \& Sociedade., Campinas, v. 24, n. 84, p. 735-762, set. 2003. Disponível em: <http://www.scielo.br/scielo.

BRASIL. Congresso. Câmara dos Deputados. Decreto Legislativo $n^{\circ}$ 1491/2014, de 28 de outubro de 2014. Susta a aplicação do Decreto $n^{\circ}$ 8.243, de 23 de maio de 2014, que institui a Política Nacional de Participação Social - PNPS e o Sistema Nacional de Participação Social - SNPS, e dá outras providências. Disponível em: <Deputadoshttp://www.camara.gov.br/proposicoesWeb/prop_mostrarintegra;jsessionid=0578 07871911C45962C7F0C38BA3F549.proposicoesWeb2?

codteor=1258271\&filename=PDC+1491/2014>. Acesso em: 17 jun. 2015.

CONDORCET, Jean-Antoine-Nicolas de Caritat, marquis, 1743-1794. Escritos Políticos Constitucionais / Condorcet. Organização, tradução e apresentação: Amaro de Oliveira Fleck e Cristina Foroni Consoni. Campinas: Unicamp, 2013.

Cinq mémoires sur l'instruction publique. Paris: Flammarion, 1994.

CONSANI, Cristina Foroni. O papel da deliberação democrática no plano constitucional de Condorcet. ethic@ - An international Journal for Moral Philosophy, Florianópolis, v. 9, n. 1, p. 59-75, jan. 2010. ISSN 1677-2954. Disponível em:<https://periodicos.ufsc.br/index.php/ethic/article/view/16772954.2010v9n1p59/18744>. Acesso em: 26 jun. 2015.

; KLEIN, Joel Thiago. Condorcet e Kant: a esperança como horizonte do projeto político. Kriterion, Belo Horizonte, v. 55, n. 129, p. 111-131, jun.2014.Disponívelem: $<\mathrm{http}: / / \mathrm{www}$. scielo.br/scielo.php?script=sci_arttext\&pid=S0100512X2014000100007\&lng=pt\&nrm=iso>. Acesso em: 2 jul. 2015.

DAL BOSCO, Maria Goretti. Discricionariedade em Políticas Públicas, um olhar Garantista da Aplicação da Lei de Improbidade Administrativa. Curitiba: Juruá, 2008. GÓES, Ricardo Tinoco. Democracia Deliberativa e Jurisdição. A Legitimidade da Decisão Judicial a partir e Para Além da Teoria de J. Habermas. Curitiba: Juruá, 2013.

HABERMAS. Consciência Moral e Agir Comunicativo. Tradução de Guido A. de 
Almeida. Rio de Janeiro: Tempo Brasileiro, 1989.

Pensamento Pós Metafísico: Estudos Filosóficos. Tradução de Flávio Bento Siebeneichler. Rio de Janeiro: Tempo Brasileiro, 1990.

Direito e Democracia. Entre facticidade e validade. Vol. I. Tradução de Flávio Bento Siebeneichler. 2. ed. Rio de Janeiro: Tempo brasileiro, 2010.

Direito e Democracia. Entre facticidade e validade. Vol. II. Tradução de Flávio Bento Siebeneichler. 2. ed. Rio de Janeiro: Tempo brasileiro, 2010.

Verdade e Justificação. Tradução de Milton Camargo Mota. São Paulo: Edições Loyola, 2004.

LIMA, Raimundo Márcio. Administração Pública Dialógica. Curitiba: Juruá, 2013.

MORAIS, José Luís de. Crise do Estado e democracia. Onde está o povo?. Democracia, Direito e Política: estudos internacionais em Homenagem a Friedrich Müller. Martonio Mont' Alverne BarretoLima; Paulo Antônio de Menezes de Albusqueque (orgs.). Florianópolis: Conceito, 2006,

MÜLLER, Friedrich. Quem é o povo? A questão fundamental da democracia. São Paulo: Max Limonad, 2000.

PIOZZI, Patrizia. Da necessidade à liberdade: uma nota sobre as propostas de Diderot e Condorcet para o ensino superior. Educ. Soc., Campinas, v. 25, n. 88, p. 655-676, out. 2004.Disponívelem:http://www.scielo.br/scielo.php?

script=sci_arttext\&pid=S010173302004000300002\&lng=pt\&nrm=iso>. Acesso em: 2 jul. 2015.

UBENOW, Jorge Adriano. Esfera pública e democracia deliberativa em Habermas: modelo teórico e discursos críticos. Kriterion, Belo Horizonte, v. 51, n. 121, p. 227258,jun.2010.Disponívelem:<http://www.scielo.br/scielo.php?

script=sci_arttext\&pid=S0100512X2010000100012\&lng=pt\&nrm=iso> Acesso em: 20 jul. 2015 .

URBINATI, Nadia. O que torna a representação democrática?. Lua Nova, São Paulo, n. 67, p. 191-228, 2000. Disponível em: <http://www.scielo.br/scielo.php? script=sci_arttext\&pid=S0102-64452006000200007 \&lng=pt\&nrm=iso >. Acesso em: $1^{\circ}$ jul. 2015. 